\title{
Analysis of clinical characteristics, laboratory findings and therapy of 134 cases of COVID-19 in Wuhan, China: a retrospective analysis.
}

Rui Zhang

Wuhan Xinzhou District People's Hospital

Jie Zhang (D945128911@qq.com )

Wuhan Xinhzhou District People's Hospital

Jiebing Chen

Wuhan Xinzhou District People's Hospital

\section{Research}

Keywords: SARS-CoV-2, COVID-19, clinical characteristics, laboratory findings, therapy, gamma globulin

Posted Date: September 21st, 2020

DOI: https://doi.org/10.21203/rs.3.rs-79418/v1

License: (a) (i) This work is licensed under a Creative Commons Attribution 4.0 International License. Read Full License 


\section{Abstract}

BackgroundXAs everyone knows, the pandemic COVID-19 is spreading in the whole world. The number of laboratory-confirmed cases reached 28,637,211 and that of the death cases was 917,404 in the world as of September $13^{\text {th }}, 2020$. We sought to analyse the clinical characteristics, laboratory findings and therapy of some cases with COVID-19.

Methods: In this retrospective study, we extracted the data on 134 patients with laboratory-confirmed COVID-19 in Wuhan Xinzhou District People's Hospital from January $16^{\text {th }}$ to April $24^{\text {th }}, 2020$. Cases were confirmed by real-time RT-PCR and abnormal radiologic findings. Outcomes were followed up until May $1^{\text {th }}, 2020$.

Results囚Co-infection and severe underlying diseases made it easier for a case with COVID-19 to develop to be a severe one or reach an outcome of death. Age above 60 years old, male and symptoms such as fever, cough, chest tightness, headaches and fatigue were related to severe COVID-19 and an outcome of death. In addition, higher temperature, blood leukocyte count, neutrophil count, C-reactive protein level, Ddimer level, alanine aminotransferase activity, aspartate aminotransferase activity, a-hydroxybutyrate dehydrogenase activity, lactate dehydrogenase activity and creatine kinase activity were also related to severe COVID-19 and an outcome of death, and so was lower lymphocyte count. Administration of gamma globulin seemed helpful for reducing the mortality of patients with severe COVID-19, however the $P$ value was greater than $0.05(P=0.180)$, which mean under the same condition, studies of larger samples are needed in the future.

Conclusion: Multiple factors were related to severe COVID-19 and an outcome of death. Administration of gamma globulin seemed helpful for reducing the mortality of severe cases. More related studies are needed in the future.

\section{Background}

As everyone knows, the pandemic COVID-19 (coronavirus disease 2019), which is caused by the coronavirus SARS-CoV-2 (severe acute respiratory syn-drome coronavirus 2), is spreading in the whole world. The number of laboratory-confirmed cases reached $28,637,211$ and that of the death cases was 917,404 in the world as of September $13^{\text {th }}, 2020$ according to the information from the official website of World Health Organization.

In the past several months a large number of studies have described the clinical characteristics and laboratory findings of patients with COVID-19 [1, 2, 3]. When assessing the relationship between potential risk factors and the severity of COVID-19, some studies used the evaluating indicator that the highest or lowest level of candidates during hospitalization while other studies mainly used the evaluating indicator that the fixed value of candidates on admission $[1,2,3]$. What are the sphere of application and clinical significance of those two evaluating indicators? And what is the relationship between those two evaluating indicators? To answer these questions, we used both the fixed value on 
admission and the highest or lowest level of candidates during hospitalization to assess the relationship between potential risk factors and the severity of COVID-19 in our study. In the discussion section, we have pointed out the risk factors related to severe COVID-19 and an outcome of death, and expounded the clinical significance of these risk factors and the role of those two evaluating indicators.

\section{Methods}

\subsection{Data sources}

We performed a retrospective study on the clinical characteristics, laboratory findings and therapy of laboratory-confirmed cases with COVID-19.

Inclusion criteria:

1. All cases were diagonosed with pneumonia based on the clinical manifestations and abnormal findings of chest X-ray or computed tomography.

2. A confirmed case with COVID-19 was defined as a positive result to high-throughput sequencing or real-time reverse-transcriptase polymerase-chain-reaction assay for nasal and pharyngeal swab specimens.

Exclusion criteria:

1. Patients with common bacteria or viruses associated with community-acquired pneumonia.

2. Patients with severe underlying disease.

3. Procalcitonin level $\otimes 5 \mathrm{ng} / \mathrm{ml}$.

A flow chart, from the total number of patients up to the 134 patients of the study $\llbracket$ was shown by Figure.1. 14 cases with severe underlying disease (i.e., chronic lung disease, chronic heart disease, chronic liver disease, chronic kidney disease) were excluded. 22 cases co-infected with COVID-19 and other respiratory pathogens (i.e., Bacteria, Chlamydia pneumoniae, Mycoplasma pneumoniae, adenovirus, and respiratory syncytial virus) associated with community-acquired pneumonia were excluded. 16 cases with both severe underlying diseases and other respiratory pathogens infection were excluded. Finally 134 confirmed cases with COVID-19 were included into our study.

All data including age, sex, temperature and laboratory findings were extracted from electronic medical records. Laboratory assessments consisted of complete blood count, blood chemistry, coagulation test, liver and renal function, C-reactive protein, a-hydroxybutyrate dehydrogenase activity, lactate dehydrogenase activity and creatine kinase activity. The severity of COVID-19 was defined accroding to the sixth edition diagnosis and treatment program of COVID-19 issued by the National Health Commission of the People's Republic of China. Finally, 100 non-severe cases and 34 severe cases were included into our study. 


\subsection{Definition of severe COVID-19}

Respiration rate $\geq 30$ times / min; at rest, oxygen saturation $\leq 93 \%$; arterial partial pressure of oxygen $(\mathrm{PaO} 2) /$ fraction of inspired oxygen $(\mathrm{FiO} 2) \leq 300 \mathrm{mmHg}$.

\subsection{Laboratory test.}

Patients usually received lab test every two days or when changing in health condition.

\subsection{Therapy with gamma globulin.}

Administration of gamma globulin was not used as conventional therapy method. Whether gamma globulin was used depended on the will of patients and their relatives.

\subsection{Statistical analysis}

Continuous variables were expressed as the medians and interquartile ranges. Categorical variables were summarized as the counts and percentages in each category. We grouped patients into severe and nonsevere cases according to the sixth edition diagnosis and treatment program of COVID-19 issued by the National Health Commission of the People's Republic of China. Wilcoxon rank-sum tests were applied to continuous variables, chi-square tests and Fisher's exact tests were used for categorical variables as appropriate. All analyses were conducted with SPSS software version 23.0 (Statistical Product and Service Solutions). Differences with $\mathrm{P}$ values $<0.05$ were considered significant.

\section{Results}

\subsection{Co-infection and severe underlying disease.}

As shown by Figure 1, 52 cases with severe underlying disease or co-infected with COVID-19 and other respiratory pathogens associated with community-acquired pneumonia were excluded, and finally 134 cases were included. Thus all the 186 patients were divided into two groups, namely included cases group and excluded cases group, as shown by Table 1.

Table 1. Compare between included cases and excluded cases

\begin{tabular}{|c|c|c|c|c|c|c|c|}
\hline \multirow[b]{2}{*}{ Groups-No., \% } & \multirow{2}{*}{$\begin{array}{l}\text { All } \\
\text { patients } \\
(\mathrm{n}=186)\end{array}$} & \multicolumn{2}{|l|}{ Disease severity } & \multirow[b]{2}{*}{ P1 } & \multicolumn{3}{|c|}{ Outcome } \\
\hline & & $\begin{array}{l}\text { No-severe } \\
(\mathrm{n}=123)\end{array}$ & $\begin{array}{l}\text { Severe } \\
(n=63)\end{array}$ & & $\begin{array}{l}\text { Survival } \\
(\mathrm{n}=166)\end{array}$ & $\begin{array}{c}\text { Death } \\
(\mathrm{n}=20)\end{array}$ & P2 \\
\hline \multirow[t]{2}{*}{$\begin{array}{l}\text { Cases included } \\
\quad(\mathrm{n}=134)\end{array}$} & $\begin{array}{c}134 / 186 \\
(66.1)\end{array}$ & $100 / 123(81.3)$ & $\begin{array}{l}34 / 63 \\
(54.0)\end{array}$ & 40.001 & $\begin{array}{c}128 / 166 \\
(77.1)\end{array}$ & $\begin{array}{c}6 / 20 \\
(30.0)\end{array}$ & $\square 0.001$ \\
\hline & & $100 / 134(74.6)$ & $\begin{array}{c}34 / 134 \\
(25.4)\end{array}$ & & $\begin{array}{c}128 / 134 \\
(95.5)\end{array}$ & $\begin{array}{c}6 / 134 \\
(4.5)\end{array}$ & \\
\hline \multirow[t]{2}{*}{$\begin{array}{l}\text { Cases excluded } \\
(n=52)\end{array}$} & $\begin{array}{l}52 / 186 \\
(33.9)\end{array}$ & 23/123 (18.7) & $\begin{array}{l}29 / 63 \\
(46.0)\end{array}$ & & $\begin{array}{l}38 / 166 \\
(22.9)\end{array}$ & $\begin{array}{l}14 / 20 \\
(70.0)\end{array}$ & \\
\hline & & $23 / 52(44.2)$ & $\begin{array}{l}29 / 52 \\
(55.8) \\
\end{array}$ & & $\begin{array}{l}38 / 52 \\
(73.1)\end{array}$ & $\begin{array}{l}14 / 52 \\
(26.9) \\
\end{array}$ & \\
\hline
\end{tabular}

P values denoted the comparison between included cases and excluded cases 
For included cases group, $25.4 \%$ of the patients were severe cases, and $4.5 \%$ of the patients died. For excluded cases group, $55.8 \%$ of the patients were severe cases and $26.9 \%$ of the patients died. (P1区0.001, P2囚0.001)

Obviously co-infection and severe underlying disease were related to severe COVID-19 and an outcome of death.

\subsection{Demographic and clinical characteristics}

The demographic and clinical characteristics are shown in Table 2. And 134 cases were included.

Table 2. Clinical characteristics of 134 patients with COVID-19 


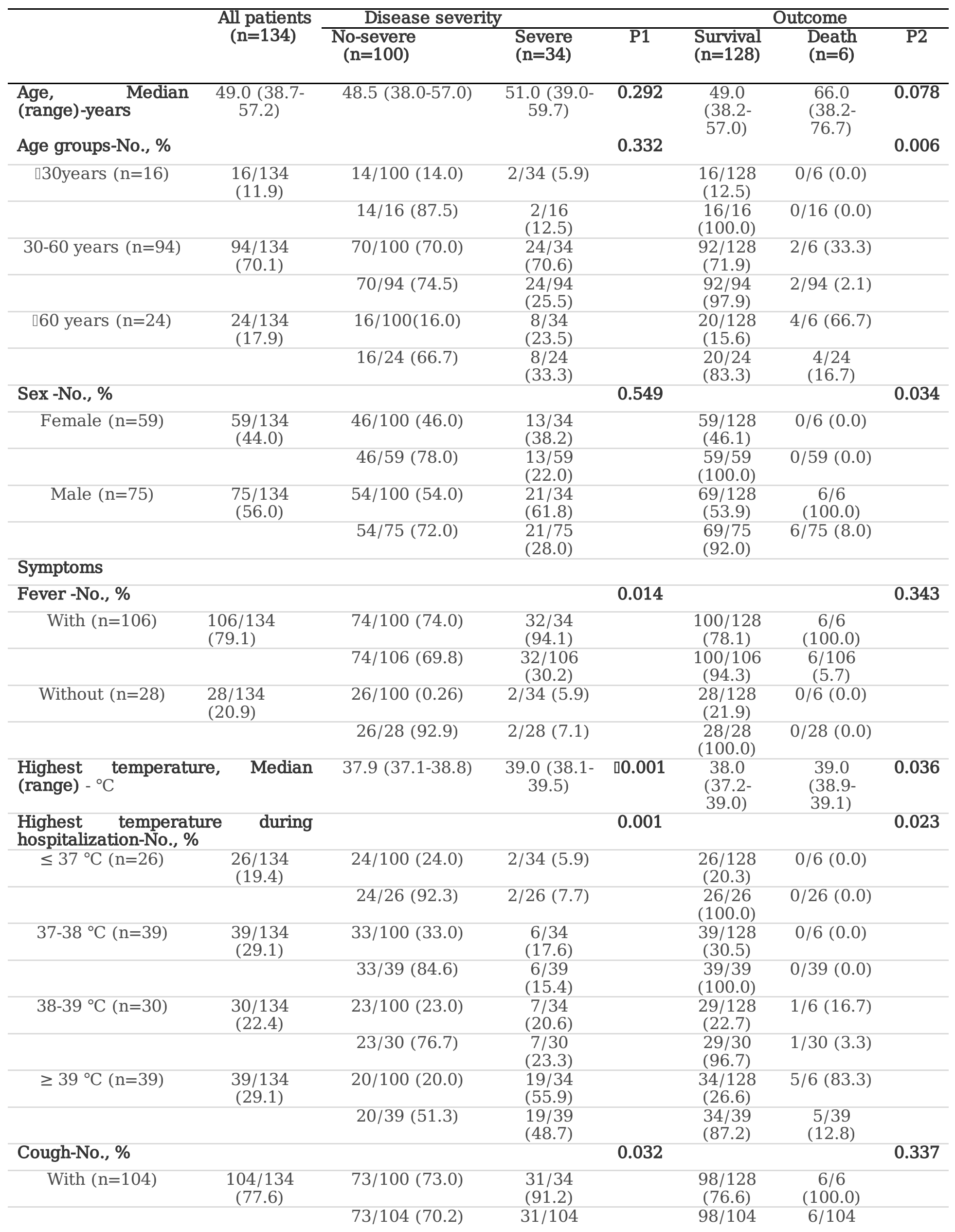




\begin{tabular}{|c|c|c|c|c|c|c|c|}
\hline & & & $\begin{array}{c}(29.8) \\
3 / 34(88)\end{array}$ & & $\begin{array}{c}(94.2) \\
30 / 128\end{array}$ & $\begin{array}{c}(5.8) \\
0 / 6(0.0)\end{array}$ & \\
\hline \multirow[t]{2}{*}{ Without $(\mathrm{n}=30)$} & $\begin{array}{c}30 / 134 \\
(22.4)\end{array}$ & 27/100 (27.0) & 3/34 (8.8) & & $\begin{array}{c}30 / 128 \\
(23.4)\end{array}$ & & \\
\hline & & $27 / 30(90.0)$ & $\begin{array}{c}3 / 30 \\
(10.0)\end{array}$ & & $\begin{array}{c}30 / 30 \\
(100.0)\end{array}$ & $0 / 6(0.0)$ & \\
\hline $\begin{array}{l}\text { Chest tightness } \\
\text { No., \% }\end{array}$ & - & & & $\square 0.001$ & & & 0.006 \\
\hline \multirow[t]{2}{*}{ With $(\mathrm{n}=59)$} & $59 / 134$ & $31 / 100(31.0)$ & $28 / 34$ & & $53 / 128$ & $6 / 6$ & \\
\hline & & $31 / 59$ (52.5) & $\begin{array}{l}28 / 59 \\
(47.5)\end{array}$ & & $\begin{array}{l}(41.4) \\
53 / 59 \\
(89.8)\end{array}$ & $\begin{array}{l}\text { (100.0) } \\
6 / 59 \\
(10.2)\end{array}$ & \\
\hline \multirow[t]{2}{*}{ Without $(n=75)$} & $\begin{array}{l}75 / 134 \\
(56.0)\end{array}$ & $69 / 100(69.0)$ & $\begin{array}{c}6 / 34 \\
(17.6)\end{array}$ & & $\begin{array}{l}75 / 128 \\
(58.6)\end{array}$ & $0 / 6(0.0)$ & \\
\hline & & $69 / 75(92.0)$ & $6 / 75(8.0)$ & & $\begin{array}{c}75 / 75 \\
(100.0)\end{array}$ & $0 / 75(0.0)$ & \\
\hline Headaches-No., \% & & & & $\square 0.001$ & & & 0.019 \\
\hline \multirow[t]{2}{*}{ With $(n=15)$} & $\begin{array}{l}15 / 134 \\
(11.2)\end{array}$ & $5 / 100(5.0)$ & $\begin{array}{l}10 / 34 \\
(29.4)\end{array}$ & & $\begin{array}{c}12 / 128 \\
(9.4)\end{array}$ & $3 / 6(50.0)$ & \\
\hline & & $5 / 15$ (33.3) & $\begin{array}{l}10 / 15 \\
(66.7)\end{array}$ & & $\begin{array}{l}12 / 15 \\
(80.0)\end{array}$ & $\begin{array}{c}3 / 15 \\
(20.0)\end{array}$ & \\
\hline \multirow[t]{2}{*}{ Without $(n=119)$} & $\begin{array}{c}119 / 134 \\
(88.8)\end{array}$ & $95 / 100(95.0)$ & $\begin{array}{l}24 / 34 \\
(70.6)\end{array}$ & & $\begin{array}{c}116 / 128 \\
(90.6)\end{array}$ & $3 / 6(50.0)$ & \\
\hline & & 95/119 (79.8) & $\begin{array}{l}24 / 119 \\
(20.2)\end{array}$ & & $\begin{array}{c}116 / 119 \\
(97.5)\end{array}$ & $\begin{array}{l}3 / 119 \\
(2.5)\end{array}$ & \\
\hline Fatigue -No., \% & & & & $\square 0.001$ & & & 0.081 \\
\hline \multirow[t]{2}{*}{ With $(n=81)$} & $\begin{array}{c}81 / 134 \\
(60.4)\end{array}$ & $49 / 100(49.0)$ & $\begin{array}{l}32 / 34 \\
(94.1)\end{array}$ & & $\begin{array}{l}75 / 128 \\
(58.6)\end{array}$ & $\begin{array}{c}6 / 6 \\
(100.0)\end{array}$ & \\
\hline & & $49 / 81(60.5)$ & $\begin{array}{l}32 / 81 \\
(39.5)\end{array}$ & & $\begin{array}{l}75 / 81 \\
(92.6)\end{array}$ & $6 / 81(7.4)$ & \\
\hline \multirow[t]{2}{*}{ Without $(n=53)$} & $\begin{array}{c}53 / 134 \\
(39.6)\end{array}$ & $51 / 100(51.0)$ & $2 / 34(5.9)$ & & $\begin{array}{c}53 / 128 \\
(41.4)\end{array}$ & $0 / 6(0.0)$ & \\
\hline & & $51 / 53(96.2)$ & $2 / 53(3.8)$ & & $\begin{array}{c}53 / 53 \\
(100.0)\end{array}$ & $0 / 53(0.0)$ & \\
\hline Diarrhea-No., \% & & & & 0.418 & & & 1.000 \\
\hline \multirow[t]{2}{*}{ With $(n=8)$} & $8 / 134(6.0)$ & $5 / 100(5.0)$ & $3 / 34(8.8)$ & & $\begin{array}{l}8 / 128 \\
(6.3)\end{array}$ & $0 / 6(0.0)$ & \\
\hline & & $5 / 8(62.5)$ & $3 / 8(37.5)$ & & $\begin{array}{c}8 / 8 \\
(100.0)\end{array}$ & $0 / 8(0.0)$ & \\
\hline \multirow[t]{2}{*}{ Without $(\mathrm{n}=126)$} & $\begin{array}{c}126 / 134 \\
(94.0)\end{array}$ & $95 / 100(95.0)$ & $\begin{array}{l}31 / 34 \\
(91.2)\end{array}$ & & $\begin{array}{c}120 / 128 \\
(93.7)\end{array}$ & $\begin{array}{c}6 / 6 \\
(100.0)\end{array}$ & \\
\hline & & $95 / 126(75.4)$ & $\begin{array}{l}31 / 126 \\
(24.6) \\
\end{array}$ & & $\begin{array}{c}120 / 126 \\
(95.2) \\
\end{array}$ & $\begin{array}{l}6 / 126 \\
(4.8) \\
\end{array}$ & \\
\hline
\end{tabular}

P1 values denoted the comparison between non-severe cases and severe cases

P2 values denoted the comparison between survival cases and death cases

\subsubsection{Age}

We grouped patients into three groups according to their age as shown by Table 2.

For囚30 years group, $12.5 \%$ of the patients were severe cases and none of the patients died. For 30-60 years group, $25.5 \%$ of the patients were severe cases and $2.1 \%$ of the patients died. For $₫ 60$ years group, $33.3 \%$ of the patients were severe cases and $16.7 \%$ of the patients died. $(P 1=0.332, P 2=0.006)$

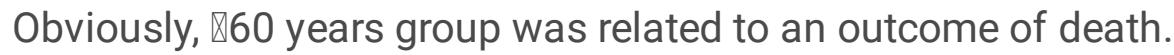

\subsubsection{Gender}


As shown by Table 2, $44.0 \%$ of the patients were female, and $56.0 \%$ of the patients were male.

For female group, $22.0 \%$ of the the patients were severe cases, and none of the patients died. For male group, $28.0 \%$ of the patients were severe cases, and $8.0 \%$ of the patients died. $(P 1=0.549, P 2=0.034)$

Obviously, male group was related to an outcome of death.

\subsubsection{Fever}

As shown by Table $2,79.1 \%$ of the patients had a fever.

For with fever group, $30.2 \%$ of the fatients were severe cases, and $5.7 \%$ of the patients died. For without fever group, $7.1 \%$ of the patients were severe cases, and none of the patients died. $(P 1=0.014, P 2=0.343)$ Obviously, with fever group was related to severe COVID-19.

\subsubsection{Temperature}

As shown by Table 2, we grouped patients into four groups according to their highest temperature during hospitalization.

For $\leq 37^{\circ} \mathrm{C}$ group, $7.7 \%$ of the patients were severe cases, and none of the patients died. For $37-38^{\circ} \mathrm{C}$ group, $15.4 \%$ of the the patients were severe cases, and none of the patients died. For $38-39^{\circ} \mathrm{C}$ group, $23.3 \%$ of the the patients were severe cases, and $3.3 \%$ of the patients died. For $\geq 39^{\circ} \mathrm{C}, 48.7 \%$ of the the patients were severe cases, and $12.8 \%$ of the patients died. $(P 1=0.001, P 2=0.023)$

Obviously, higher temperature was related to severe COVID-19 and an outcome of death.

\subsubsection{Cough}

As shown by Table $2,77.6 \%$ of the patients had a cough.

For with cough group, $29.8 \%$ of the fatients were severe cases, and $5.8 \%$ of the patients died. For without cough group, $10.0 \%$ of the patients were severe cases, and none of the patients died. ( $P 1=0.032$, $\mathrm{P} 2=0.337)$

Obviously, with cough group was related to severe COVID-19.

\subsubsection{Chest tightness}

As shown by Table $2,44.0 \%$ of the patients had chest tightness.

For with chest tightness group, $47.5 \%$ of the fatients were severe cases, and $10.2 \%$ of the patients died. For without chest tightness group, $8.0 \%$ of the patients were severe cases, and none of the patients died. $(\mathrm{P} 1 \otimes 0.001, \mathrm{P} 2=0.006)$ 
Obviously, with chest tightness group was related to severe COVID-19 and an outcome of death.

\subsubsection{Headaches}

As shown by Table $2,11.2 \%$ of the patients had headaches.

For with headaches group, $66.7 \%$ of the fatients were severe cases, and $20.0 \%$ of the patients died. For without headaches group, $20.2 \%$ of the patients were severe cases, and $2.5 \%$ of the patients died. (P1】 $0.001, \mathrm{P} 2=0.019)$

Obviously, with headaches group was related to severe COVID-19 and an outcome of death.

\subsubsection{Fatigue}

As shown by Table $2,60.4 \%$ of the patients had fatigue symptom.

For with fatigue group, $39.5 \%$ of the fatients were severe cases, and $7.4 \%$ of the patients died. For without fatigue group, $3.8 \%$ of the patients were severe cases, and none of the patients died. (P1ه0.001, $\mathrm{P} 2=0.081)$

Obviously, with fatigue group was related to severe COVID-19.

\subsubsection{Diarrhea}

As shown by Table $2,6.0 \%$ of the patients had diarrhea.

For with diarrhea group, $37.5 \%$ of the fatients were severe cases, and none of the patients died. For without diarrhea group, $24.6 \%$ of the patients were severe cases, and $4.8 \%$ of the patients died.

However, the $\mathrm{P}$ values were greater than $0.05(\mathrm{P} 1=0.418, \mathrm{P} 2=1.000)$, which mean under the same condition, studies of larger samples are needed in the future.

\subsection{Laboratory findings}

The Laboratory findings are shown by Table 3 and Table 4 .

Table 3. Laboratory findings of 134 patients with COVID-19 


\begin{tabular}{|c|c|c|c|c|c|c|c|}
\hline \multirow{2}{*}{ oratory findings } & \multirow{2}{*}{$\begin{array}{l}\text { All patients } \\
(\mathrm{n}=134)\end{array}$} & \multicolumn{2}{|c|}{ Disease severity } & \multicolumn{3}{|c|}{ Outcome } & \\
\hline & & $\begin{array}{c}\text { No-severe } \\
(\mathrm{n}=100)\end{array}$ & $\begin{array}{l}\text { Severe } \\
(n=34)\end{array}$ & $\overline{\text { P1 }}$ & $\begin{array}{l}\text { Survival } \\
(\mathrm{n}=128)\end{array}$ & $\begin{array}{l}\text { Death } \\
(n=6)\end{array}$ & $\mathrm{P} 2$ \\
\hline
\end{tabular}

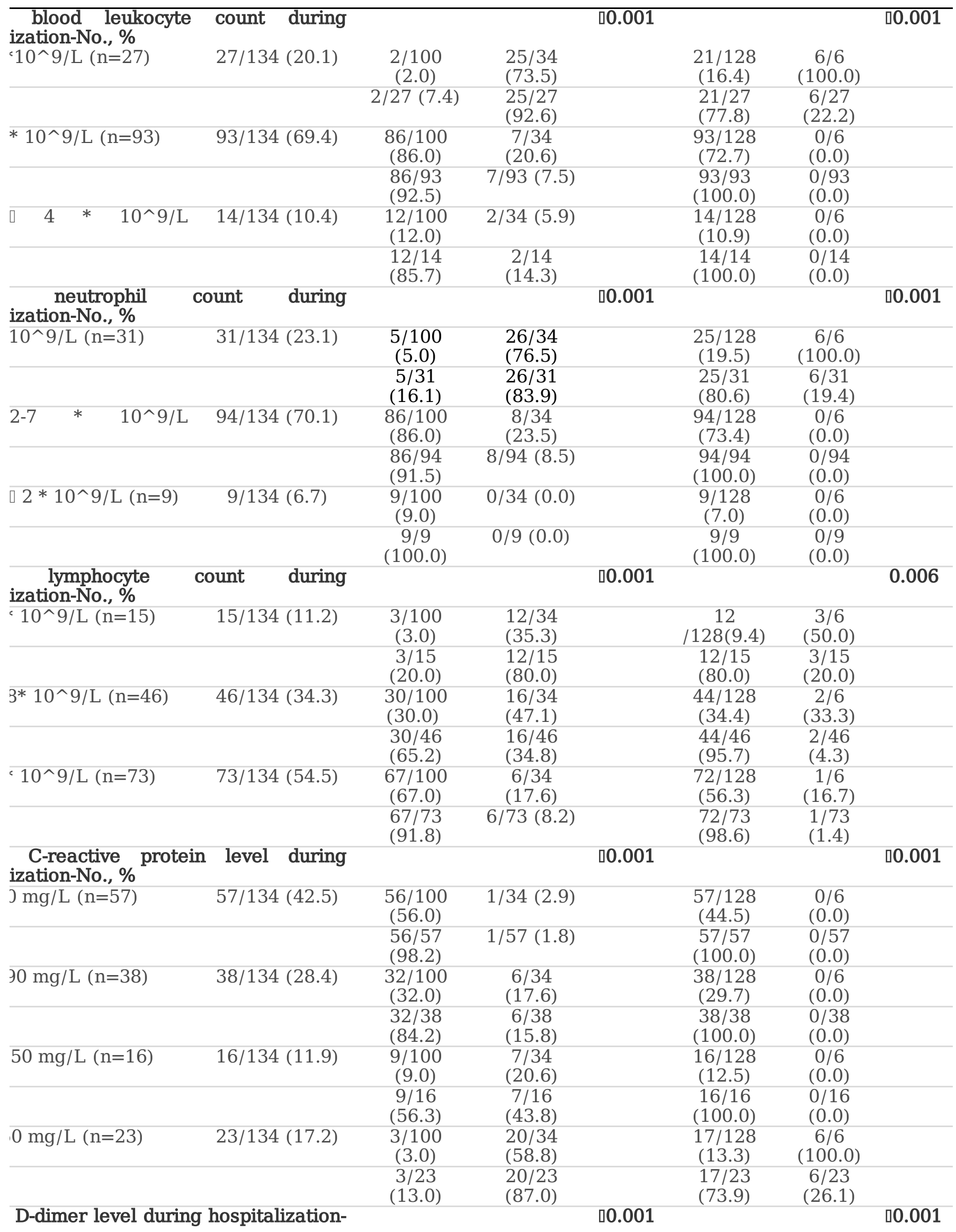




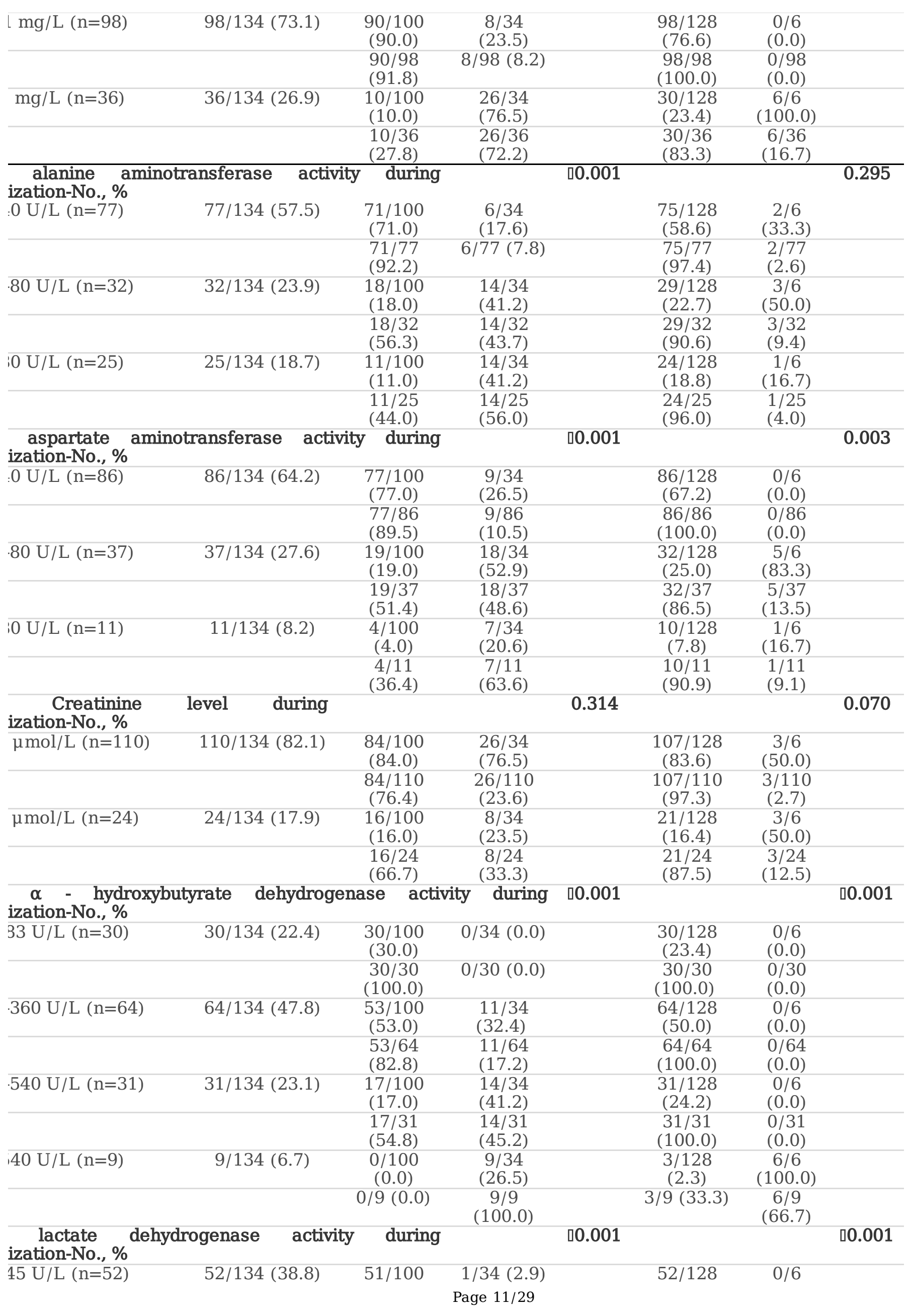




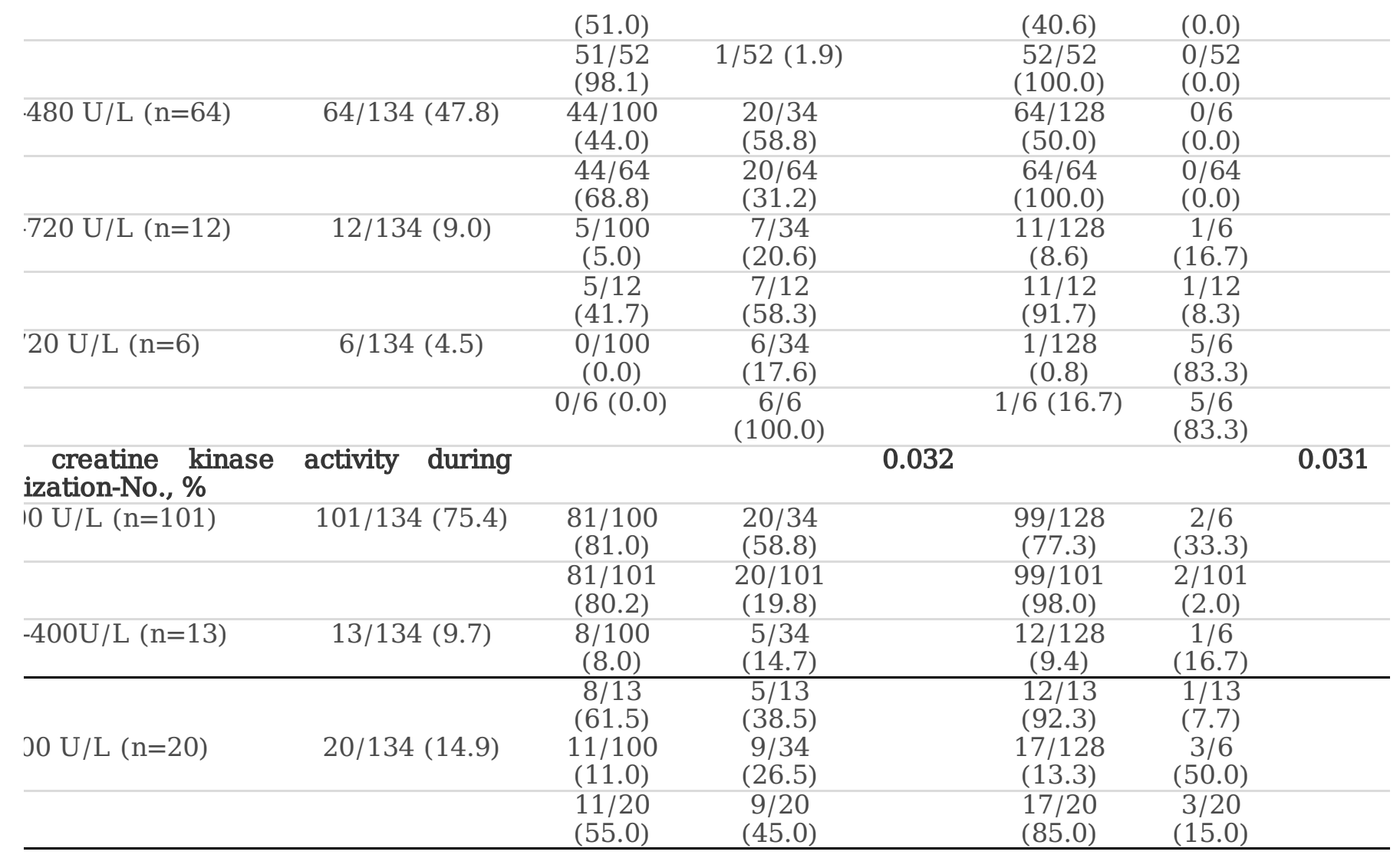

P1 values denoted the comparison between non-severe cases and severe cases

P2 values denoted the comparison between survival cases and death cases

Table 4. Laboratory findings of 134 patients with COVID-19 


\begin{tabular}{|c|c|c|c|c|c|c|c|}
\hline \multirow[b]{2}{*}{ Laboratory findings } & \multirow{2}{*}{$\begin{array}{c}\text { All patients } \\
(\mathrm{n}=134)\end{array}$} & \multicolumn{2}{|c|}{ Disease severity } & \multicolumn{3}{|c|}{ Outcome } & \multirow[b]{2}{*}{$\overline{\mathrm{P} 2}$} \\
\hline & & $\begin{array}{c}\text { No-severe } \\
(n=100)\end{array}$ & $\begin{array}{l}\text { Severe } \\
(n=34)\end{array}$ & P1 & $\begin{array}{l}\text { Survival } \\
(\mathrm{n}=128)\end{array}$ & $\begin{array}{l}\text { Death } \\
(n=6)\end{array}$ & \\
\hline \multicolumn{2}{|c|}{$\begin{array}{l}\text { Blood leukocyte count on admission,-- } \\
\text { No. \% }\end{array}$} & & & 00.001 & & & 0.001 \\
\hline \multirow[t]{2}{*}{$>10^{*} 10^{\wedge} 9 / \mathrm{L}(\mathrm{n}=11)$} & $11 / 134(8.2)$ & $1 / 100(1.0)$ & $\begin{array}{l}10 / 34 \\
(14.7)\end{array}$ & & $8 / 128(6.3)$ & $\begin{array}{c}3 / 6 \\
(50.0)\end{array}$ & \\
\hline & & $1 / 11(9.1)$ & $\begin{array}{l}10 / 11 \\
(90.9)\end{array}$ & & $8 / 11$ (72.7) & $\begin{array}{l}3 / 11 \\
(27.3)\end{array}$ & \\
\hline \multirow[t]{2}{*}{$4-10 * 10^{\wedge} 9 / \mathrm{L}(\mathrm{n}=94)$} & $\begin{array}{l}94 / 134 \\
(70.1)\end{array}$ & $\begin{array}{l}75 / 100 \\
(75.0)\end{array}$ & $\begin{array}{l}19 / 34 \\
(55.9)\end{array}$ & & $\begin{array}{l}91 / 128 \\
(71.1)\end{array}$ & $\begin{array}{c}3 / 6 \\
(50.0)\end{array}$ & \\
\hline & & $\begin{array}{l}75 / 94 \\
(79.8)\end{array}$ & $\begin{array}{l}19 / 94 \\
(20.2)\end{array}$ & & $91 / 94(96.8)$ & $\begin{array}{l}3 / 94 \\
(3.2)\end{array}$ & \\
\hline \multirow[t]{2}{*}{$(\mathrm{n}=29)^{\square} 4 * 10^{\wedge} 9 / \mathrm{L}$} & $\begin{array}{l}29 / 134 \\
(21.6)\end{array}$ & $\begin{array}{l}24 / 100 \\
(24.0)\end{array}$ & $5 / 34(29.4)$ & & $\begin{array}{l}29 / 128 \\
(22.7)\end{array}$ & $0 / 6(0.0)$ & \\
\hline & & $\begin{array}{l}24 / 29 \\
(82.8)\end{array}$ & $5 / 29(17.2)$ & & $\begin{array}{l}29 / 29 \\
(100.0)\end{array}$ & $\begin{array}{l}0 / 29 \\
(0.0)\end{array}$ & \\
\hline \multicolumn{2}{|c|}{ Neutrophil count on admission-No., \% } & & & $\square 0.001$ & & & $\square 0.001$ \\
\hline \multirow[t]{2}{*}{$>7 * 10^{\wedge} 9 / \mathrm{L}(\mathrm{n}=18)$} & $\begin{array}{c}18 / 134 \\
(13.4)\end{array}$ & $2 / 100(2.0)$ & $\begin{array}{l}16 / 34 \\
(47.1)\end{array}$ & & $\begin{array}{l}14 / 128 \\
(10.9)\end{array}$ & $\begin{array}{l}4 / 6 \\
(66.7)\end{array}$ & \\
\hline & & $2 / 18(11.1)$ & $\begin{array}{l}16 / 18 \\
(88.9)\end{array}$ & & $14 / 18(77.8)$ & $\begin{array}{c}4 / 18 \\
(22.2)\end{array}$ & \\
\hline \multirow[t]{2}{*}{$(\mathrm{n}=94)^{2-7} *{ }^{2} \quad 10^{\wedge} 9 / \mathrm{L}$} & $\begin{array}{l}94 / 134 \\
(70.1)\end{array}$ & $\begin{array}{l}79 / 100 \\
(79.0)\end{array}$ & $\begin{array}{l}15 / 34 \\
(44.1)\end{array}$ & & $\begin{array}{l}92 / 128 \\
(71.9)\end{array}$ & $\begin{array}{c}2 / 6 \\
(33.3)\end{array}$ & \\
\hline & & $\begin{array}{l}79 / 94 \\
(84.0)\end{array}$ & $\begin{array}{l}15 / 94 \\
(16.0)\end{array}$ & & $92 / 94(97.9)$ & $\begin{array}{l}2 / 94 \\
(2.1)\end{array}$ & \\
\hline \multirow[t]{2}{*}{$(\mathrm{n}=22)^{\square}$} & $\begin{array}{l}22 / 134 \\
(16.4)\end{array}$ & $\begin{array}{l}19 / 100 \\
(19.0)\end{array}$ & $3 / 34(8.8)$ & & $\begin{array}{l}22 / 128 \\
(17.2)\end{array}$ & $0 / 6(0.0)$ & \\
\hline & & $\begin{array}{l}19 / 22 \\
(86.4)\end{array}$ & $3 / 22(13.6)$ & & $\begin{array}{l}22 / 22 \\
(100.0)\end{array}$ & $\begin{array}{l}0 / 22 \\
(0.0)\end{array}$ & \\
\hline \multicolumn{2}{|c|}{$\begin{array}{l}\text { Lymphocyte count on admission-No., } \\
\%\end{array}$} & & & 00.001 & & & $\square 0.001$ \\
\hline \multirow[t]{2}{*}{$\square 0.4^{*} 10^{\wedge} 9 / \mathrm{L}(\mathrm{n}=4)$} & $4 / 134(3.0)$ & $0 / 100(0.0)$ & $4 / 34(11.8)$ & & $2 / 128(1.6)$ & $\begin{array}{c}2 / 6 \\
(33.3)\end{array}$ & \\
\hline & & $0 / 4(0.0)$ & $4 / 4(100.0)$ & & $2 / 4(50.0)$ & $\begin{array}{c}2 / 4 \\
(50.0)\end{array}$ & \\
\hline \multirow[t]{2}{*}{$0.4-0.8 * 10 \wedge 9 / L(n=36)$} & $\begin{array}{l}36 / 134 \\
(26.9)\end{array}$ & $\begin{array}{l}23 / 100 \\
(23.0)\end{array}$ & $\begin{array}{l}13 / 34 \\
(38.2)\end{array}$ & & $\begin{array}{l}35 / 128 \\
(27.3)\end{array}$ & $\begin{array}{c}1 / 6 \\
(16.7)\end{array}$ & \\
\hline & & $\begin{array}{l}23 / 36 \\
(63.9)\end{array}$ & $\begin{array}{l}13 / 36 \\
(36.1)\end{array}$ & & $35 / 36(97.2)$ & $\begin{array}{l}1 / 36 \\
(2.8)\end{array}$ & \\
\hline \multirow[t]{2}{*}{ [0.8* 10^9/L (n=94) } & $\begin{array}{l}94 / 134 \\
(70.1)\end{array}$ & $\begin{array}{l}77 / 100 \\
(77.0)\end{array}$ & $\begin{array}{l}17 / 34 \\
(50.0)\end{array}$ & & $\begin{array}{l}91 / 128 \\
(71.1)\end{array}$ & $\begin{array}{c}3 / 6 \\
(50.0)\end{array}$ & \\
\hline & & $\begin{array}{l}77 / 94 \\
(81.9)\end{array}$ & $\begin{array}{l}17 / 94 \\
(18.1)\end{array}$ & & $91 / 94(96.8)$ & $\begin{array}{l}3 / 94 \\
(3.2)\end{array}$ & \\
\hline \multicolumn{2}{|c|}{$\begin{array}{l}\text { C-reactive protein level on admission- } \\
\text { No., \% }\end{array}$} & & & 00.001 & & & 0.009 \\
\hline \multirow[t]{2}{*}{$\square 20 \mathrm{mg} / \mathrm{L}(\mathrm{n}=68)$} & $\begin{array}{l}68 / 134 \\
(50.7)\end{array}$ & $\begin{array}{l}65 / 100 \\
(65.0)\end{array}$ & $3 / 34(8.8)$ & & $\begin{array}{l}68 / 128 \\
(53.1)\end{array}$ & $0 / 6(0.0)$ & \\
\hline & & $\begin{array}{l}65 / 68 \\
(95.6)\end{array}$ & $3 / 68(4.4)$ & & $\begin{array}{c}68 / 68 \\
(100.0)\end{array}$ & $\begin{array}{l}0 / 68 \\
(0.0)\end{array}$ & \\
\hline \multirow[t]{2}{*}{$20-90 \mathrm{mg} / \mathrm{L}(\mathrm{n}=42)$} & $\begin{array}{l}42 / 134 \\
(31.3)\end{array}$ & $\begin{array}{l}28 / 100 \\
(28.0)\end{array}$ & $\begin{array}{l}14 / 34 \\
(41.2)\end{array}$ & & $\begin{array}{l}40 / 128 \\
(31.3)\end{array}$ & $\begin{array}{c}2 / 6 \\
(33.3)\end{array}$ & \\
\hline & & $\begin{array}{l}28 / 42 \\
(66.7)\end{array}$ & $\begin{array}{l}14 / 42 \\
(33.3)\end{array}$ & & $40 / 42(95.2)$ & $\begin{array}{l}2 / 42 \\
(4.8)\end{array}$ & \\
\hline \multirow[t]{2}{*}{$90-150 \mathrm{mg} / \mathrm{L}(\mathrm{n}=11)$} & $11 / 134(8.2)$ & $4 / 100(4.0)$ & $7 / 34(20.6)$ & & $9 / 128(7.0)$ & $\begin{array}{c}2 / 6 \\
(33.3)\end{array}$ & \\
\hline & & $4 / 11(36.4)$ & $7 / 11(63.6)$ & & 9/11 (81.8) & $\begin{array}{c}2 / 11 \\
(18.2)\end{array}$ & \\
\hline \multirow[t]{2}{*}{$0150 \mathrm{mg} / \mathrm{L}(\mathrm{n}=13)$} & $13 / 134(9.7)$ & $3 / 100(3.0)$ & $\begin{array}{l}10 / 34 \\
(29.4)\end{array}$ & & $11 / 128(8.6)$ & $\begin{array}{c}2 / 6 \\
(33.3)\end{array}$ & \\
\hline & & $3 / 13(23.1)$ & $\begin{array}{l}10 / 13 \\
(76.9)\end{array}$ & & $11 / 13(84.6)$ & $\begin{array}{c}2 / 13 \\
(15.4)\end{array}$ & \\
\hline \multicolumn{2}{|c|}{ D-dimer level on admission-No., \% } & & & $\square 0.001$ & & & 0.037 \\
\hline$\leq 1 \mathrm{mg} / \mathrm{L}(\mathrm{n}=115)$ & $115 / 134$ & $95 / 100$ & $20 / 34$ & & $112 / 128$ & $3 / 6$ & \\
\hline
\end{tabular}




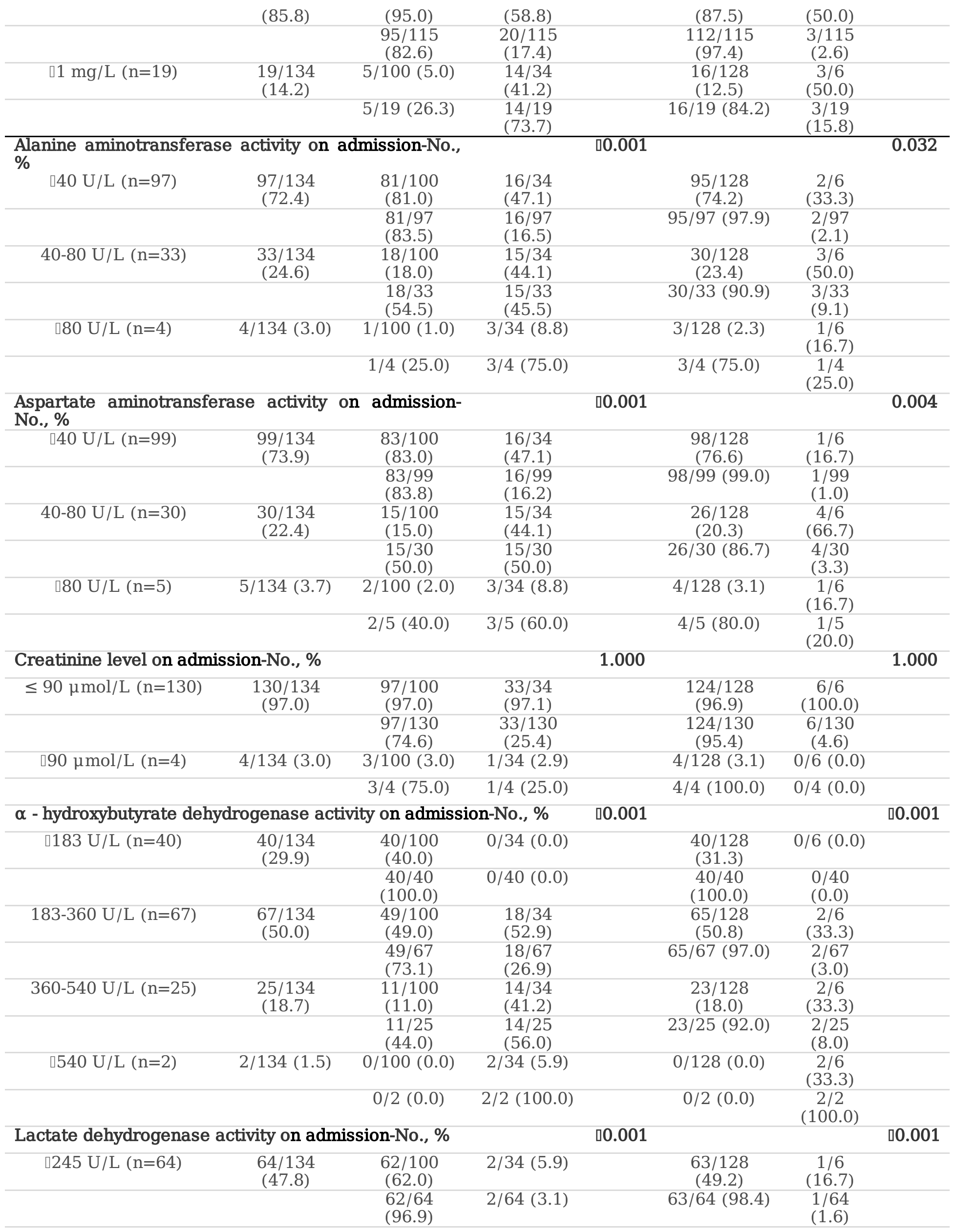




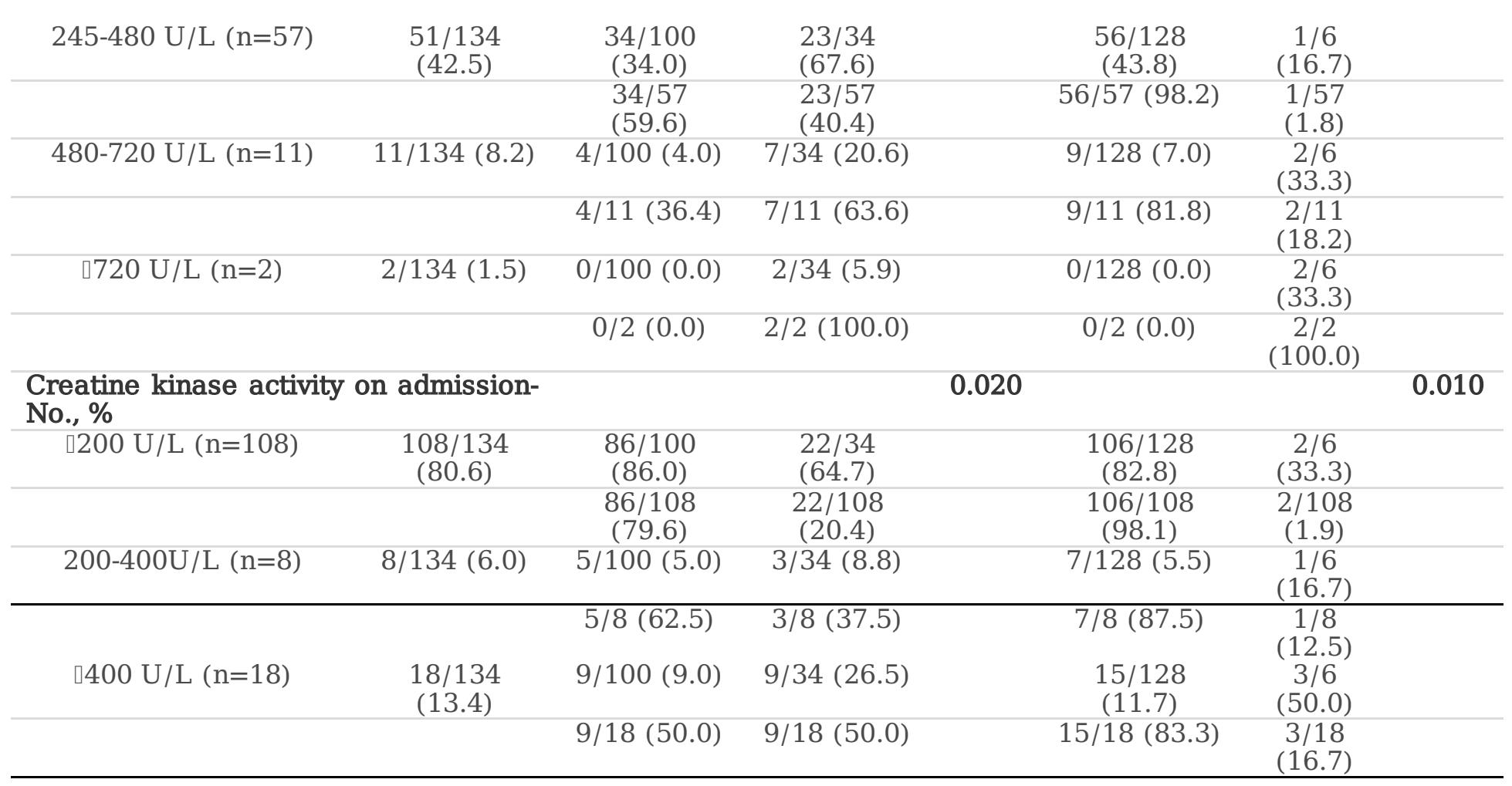

P1 values denoted the comparison between non-severe cases and severe cases

P2 values denoted the comparison between survival cases and death cases

\subsubsection{Blood leukocyte count}

\subsubsection{Highest blood leukocyte count during hospitalization}

As shown by Table 3, we grouped patients into three groups according to their highest blood leukocyte count during hospitalization.

For $>10 * 10^{\wedge} 9 / \mathrm{L}$ group, $92.6 \%$ of the patients were severe cases, and $22.2 \%$ of the patients died. For $4-10$ * $10^{\wedge} 9 / \mathrm{L}$ group, $7.5 \%$ of the patients were severe cases, and none of the patients died. For $\nabla 4 * 10^{\wedge} 9 / \mathrm{L}$ group, $14.3 \%$ of the patients were severe cases, and none of the patients died. (P1ه0.001, P2ख0.001) $>10^{\star} 10^{\wedge} 9 / \mathrm{L}$ group was strongly related to severe COVID-19 and an outcome of death.

\subsubsection{Blood leukocyte count on admission}

As shown by Table 4, we grouped patients into three groups according to their blood leukocyte count on admission.

For $>10 * 10^{\wedge} 9 / \mathrm{L}$ group, $90.9 \%$ of the patients were severe cases, and $27.3 \%$ of the patients died. For $4-10$ * $10^{\wedge} 9 / \mathrm{L}$ group, $20.2 \%$ of the patients were severe cases, and $3.2 \%$ of the patients died. For $\nabla 4 * 10^{\wedge} 9 / \mathrm{L}$ group, $17.2 \%$ of the patients were severe cases, and none of the patients died. (P1『0.001, P2ه0.001) $>10^{\star} 10^{\wedge} 9 / \mathrm{L}$ group was strongly related to severe COVID-19 and an outcome of death. 


\subsection{Neutrophils}

\subsubsection{Highest neutrophil count during hospitalization}

As shown by Table 3, we grouped patients into three groups according to their highest neutrophil count during hospitalization.

For $>7 * 10^{\wedge} 9 / \mathrm{L}$ group, $83.9 \%$ of the patients were severe cases, and $19.4 \%$ of the patients died. For $2-7$ * $10^{\wedge} 9 / \mathrm{L}$ group, $8.5 \%$ of the patients were severe cases, and none of the patients died. For $\nabla 2 * 10^{\wedge} 9 / \mathrm{L}$ group, none of the patients were severe cases, and none of the patients died. (P1ه0.001, P2ه0.001)

$>7 \star 10^{\wedge} 9 / \mathrm{L}$ group was strongly related to severe COVID-19 and an outcome of death.

\subsubsection{Neutrophil count on admission}

As shown by Table 4, we grouped patients into three groups according to their neutrophil count on admission.

For $>7 * 10^{\wedge} 9 / \mathrm{L}$ group, $88.9 \%$ of the patients were severe cases, and $22.2 \%$ of the patients died. For $2-7$ * $10^{\wedge} 9 / \mathrm{L}$ group, $16.0 \%$ of the patients were severe cases, and $2.1 \%$ of the patients died. For $\mathbb{2} 2 * 10^{\wedge} 9 / \mathrm{L}$ group, $13.6 \%$ of the patients were severe cases, and none of the patients died. (P1『0.001, P2ख0.001)

$>7 * 10^{\wedge} 9 / \mathrm{L}$ group was strongly related to severe COVID-19 and an outcome of death.

\subsection{3 lymphocyte}

\subsubsection{Lowest lymphocyte count during hospitalization}

As shown by Table 3, we grouped patients into three groups according to their Lowest lymphocyte count during hospitalization.

For $₫ 0.4^{\star} 10^{\wedge} 9 / \mathrm{L}$ group, $80.0 \%$ of the patients were severe cases, and $20.0 \%$ of the patients died. For 0.4 -

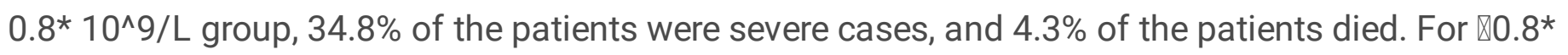
$10^{\wedge} 9 / \mathrm{L}$ group, $8.2 \%$ of the patients were severe cases, and $1.4 \%$ of the patients died. (P1ه0.001, P2 $\varangle 0.001$ )

Lower lymphocyte count was strongly related to severe COVID-19 and an outcome of death.

\subsubsection{Lymphocyte percentage on admission}

As shown by Table 4, we grouped patients into three groups according to their lymphocyte count on admission.

For $\otimes 0.4^{*} 10^{\wedge} 9 / \mathrm{L}$ group, all of the patients were severe cases, and $50.0 \%$ of the patients died. For $0.4-0.8^{*}$ $10^{\wedge} 9 / \mathrm{L}$ group, $36.1 \%$ of the patients were severe cases, and $2.8 \%$ of the patients died. For $\nabla 0.8^{\star} 10^{\wedge} 9 / \mathrm{L}$ group, $18.1 \%$ of the patients were severe cases, and $3.2 \%$ of the patients died. (P1ه0.001, P2 $\varangle 0.001$ ) 
Lower lymphocyte count was strongly related to severe COVID-19 and an outcome of death.

\subsubsection{C-reactive protein level}

\subsubsection{Highest C-reactive protein level during hospitalization}

As shown by Table 3, we grouped patients into four groups according to their highest C-reactive protein level during hospitalization.

For $\ 20 \mathrm{mg} / \mathrm{L}$ groups, $1.8 \%$ of the patients were severe cases, and none of the patients died. For $20-90$ $\mathrm{mg} / \mathrm{L}$ group, $15.8 \%$ of the patients were severe cases, and none of the patients died. For $90-150 \mathrm{mg} / \mathrm{L}$ group, $43.8 \%$ of the patients were severe cases, and none of the patients died. For $\otimes 150 \mathrm{mg} / \mathrm{L}$ group, $87.0 \%$ of the patients were severe cases, and $26.1 \%$ of the patients died. (P1 $₫ 0.001, \mathrm{P} 2 \varangle 0.001)$

Higher C-reactive protein level was strongly related to severe COVID-19 and an outcome of death.

\subsubsection{C-reactive protein level on admission}

As shown by Table 4, we grouped patients into four groups according to their C-reactive protein level on admission.

For $\ 20 \mathrm{mg} / \mathrm{L}$ groups, $4.4 \%$ of the patients were severe cases, and none of the patients died. For $20-90$ $\mathrm{mg} / \mathrm{L}$ group, $33.3 \%$ of the patients were severe cases, and $4.8 \%$ of the patients died. For $90-150 \mathrm{mg} / \mathrm{L}$ group, $63.6 \%$ of the patients were severe cases, and $18.2 \%$ of the patients died. For $\$ 150 \mathrm{mg} / \mathrm{L}$ group, $76.9 \%$ of the patients were severe cases, and $15.4 \%$ of the patients died. (P1ख0.001, P2 $=0.009$ )

Higher C-reactive protein level was strongly related to severe COVID-19.

\subsubsection{D-dimer level}

\subsubsection{Highest D-dimer level during hospitalization}

As shown by Table 3, we grouped patients into two groups according to their highest D-dimer level during hospitalization.

For $\leq 1 \mathrm{mg} / \mathrm{L}$ group, $8.2 \%$ of the patients were severe cases, and none of the patients died. For $\ 1 \mathrm{mg} / \mathrm{L}$ group, $72.2 \%$ of the patients were severe cases, and $16.7 \%$ of the patients died. (P1ه0.001, P2 $\varangle 0.001$ )

Higher D-dimer level was strongly related to severe COVID-19 and an outcome of death.

\subsubsection{D-dimer level on admission}

As shown by Table 4, we grouped patients into two groups according to their D-dimer level on admission.

For $\leq 1 \mathrm{mg} / \mathrm{L}$ group, $17.4 \%$ of the patients were severe cases, and $2.6 \%$ of the patients died. For $\ 1 \mathrm{mg} / \mathrm{L}$ group, $73.7 \%$ of the patients were severe cases, and $15.8 \%$ of the patients died. (P1ه0.001, P2=0.037) 
Higher D-dimer level was strongly related to severe COVID-19 and an outcome of death.

\subsubsection{Alanine aminotransferase activity}

\subsubsection{Highest alanine aminotransferase activity during hospitalization}

As shown by Table 3, we grouped patients into three groups according to their highest alanine aminotransferase activity during hospitalization.

For $₫ 40 \mathrm{U} / \mathrm{L}$ group, $7.8 \%$ of the patients were severe cases, and $2.6 \%$ of the patients died. For $40-80 \mathrm{U} / \mathrm{L}$ group, $43.7 \%$ of the patients were severe cases, and $9.4 \%$ of the patients died. For $\$ 80 \mathrm{U} / \mathrm{L}$ group, $56.0 \%$ of the patients were severe cases, and $4.0 \%$ of the patients died. $(P 1 \otimes 0.001, P 2=0.295)$

Higher alanine aminotransferase activity was related to severe COVID-19.

\subsubsection{Alanine aminotransferase activity on admission}

As shown by Table 4, we grouped patients into three groups according to their alanine aminotransferase activity on admission.

For $\$ 40 \mathrm{U} / \mathrm{L}$ group, $16.5 \%$ of the patients were severe cases, and $2.1 \%$ of the patients died. For $40-80 \mathrm{U} / \mathrm{L}$ group, $45.5 \%$ of the patients were severe cases, and $9.1 \%$ of the patients died. For $\$ 80 \mathrm{U} / \mathrm{L}$ group, $75.0 \%$ of the patients were severe cases, and $25.0 \%$ of the patients died. $(P 1 \otimes 0.001, P 2=0.032)$

Higher alanine aminotransferase activity was related to severe COVID-19 and an outcome of death.

\subsubsection{Aspartate aminotransferase activity}

\subsubsection{Highest aspartate aminotransferase activity during hospitalization}

As shown by Table 3, we grouped patients into three groups according to their highest aspartate aminotransferase activity during hospitalization.

For $\$ 40 \mathrm{U} / \mathrm{L}$ group, $10.5 \%$ of the patients were severe cases, and none of the patients died. For $40-80 \mathrm{U} / \mathrm{L}$ group, $48.6 \%$ of the patients were severe cases, and $13.5 \%$ of the patients died. For $\$ 80 \mathrm{U} / \mathrm{L}$ group, $63.6 \%$ of the patients were severe cases, and $9.1 \%$ of the patients died. (P1凶0.001, P2=0.003)

Higher aspartate aminotransferase activity was related to severe COVID-19.

\subsubsection{Aspartate aminotransferase activity on admission}

As shown by Table 4, we grouped patients into three groups according to their aspartate aminotransferase activity on admission

For $\$ 40 \mathrm{U} / \mathrm{L}$ group, $16.2 \%$ of the patients were severe cases, and $1.0 \%$ of the patients died. For $40-80 \mathrm{U} / \mathrm{L}$ group, $50.0 \%$ of the patients were severe cases, and $3.3 \%$ of the patients died. For $80 \mathrm{U} / \mathrm{L}$ group, $60.0 \%$ of 
the patients were severe cases, and $20.0 \%$ of the patients died. (P1区0.001, P2=0.004)

Higher aspartate aminotransferase activity was related to severe COVID-19 and an outcome of death.

\subsubsection{Creatinine level}

\subsubsection{Highest creatinine level during hospitalization}

As shown by Table 3, we grouped patients into two groups according to their highest creatinine level during hospitalization.

For $\leq 90 \mu \mathrm{mol} / \mathrm{L}$ group, $23.6 \%$ of the patients were severe cases, and $2.7 \%$ of the patients died. For $\$ 90$ $\mu \mathrm{mol} / \mathrm{L}$ group, $33.3 \%$ of the patients were severe cases, and $12.5 \%$ of the patients died.

However, the P values were greater than $0.05(\mathrm{P} 1=0.314, \mathrm{P} 2=0.07)$, which mean under the same condition, studies of larger samples are needed in the future.

\subsubsection{Creatinine level on admission}

As shown by Table 4, we grouped patients into two groups according to their creatinine level on admission.

For $\leq 90 \mu \mathrm{mol} / \mathrm{L}$ group, $25.4 \%$ of the patients were severe cases, and $4.6 \%$ of the patients died. For $\$ 90$ $\mu \mathrm{mol} / \mathrm{L}$ group, $25.0 \%$ of the patients were severe cases, and none of the patients died.

However, the $P$ values were greater than $0.05(P 1=1.000, P 2=1.000)$, which mean under the same condition, studies of larger samples are needed in the future.

\subsection{9 a-hydroxybutyrate dehydrogenase activity}

\subsubsection{Highest a-hydroxybutyrate dehydrogenase activity during hospitalization}

As shown by Table 3, we grouped patients into four groups according to their highest a-hydroxybutyrate dehydrogenase activity during hospitalization.

For冈183 U/L group, none of the patients were severe cases, and none of the patients died. For 183-360 $\mathrm{U} / \mathrm{L}$ group, $17.2 \%$ of the patients were severe cases, and none of the patients died. For 360-540 U/L group, $45.2 \%$ of the patients were severe cases, and none of the patients died. For $₫ 540 \mathrm{U} / \mathrm{L}$ group, all of the patients were severe cases, and $66.7 \%$ of the patients died. (P1ه0.001, P2ه0.001)

Higher a-hydroxybutyrate dehydrogenase activity was related to severe COVID-19 and an outcome of death.

\subsection{9.a-hydroxybutyrate dehydrogenase activity on admission}


As shown by Table 4, we grouped patients into four groups according to their a-hydroxybutyrate dehydrogenase activity on admission.

For冈183 U/L group, none of the patients were severe cases, and none of the patients died. For 183-360 $\mathrm{U} / \mathrm{L}$ group, $26.9 \%$ of the patients were severe cases, and 3.0\% of the patients died. For 360-540 U/L group, $56.0 \%$ of the patients were severe cases, and $8.0 \%$ of the patients died. For $\ 540 \mathrm{U} / \mathrm{L}$ group, all of the patients were severe cases, and all of the patients died. (P1ه0.001, P2ه0.001)

Higher a-hydroxybutyrate dehydrogenase activity was related to severe COVID-19 and an outcome of death.

\subsubsection{Lactate dehydrogenase activity}

\subsubsection{Highest lactate dehydrogenase activity during hospitalization}

As shown by Table 3, we grouped patients into four groups according to their highest lactate dehydrogenase activity during hospitalization.

For $245 \mathrm{U} / \mathrm{L}$ group, $1.9 \%$ of the patients were severe cases, and none of the patients died. For $245-480$ $\mathrm{U} / \mathrm{L}$ group, $31.2 \%$ of the patients were severe cases, and none of the patients died. For $480-720 \mathrm{U} / \mathrm{L}$ group, $58.3 \%$ of the patients were severe cases, and $8.3 \%$ of the patients died. For $\$ 720 \mathrm{U} / \mathrm{L}$ group, all of the patients were severe cases, and $83.3 \%$ of the patients died. (P1凶0.001, P2ख0.001)

Higher lactate dehydrogenase activity was related to severe COVID-19 and an outcome of death.

\subsubsection{Lactate dehydrogenase activity on admission}

As shown by Table 4, we grouped patients into four groups according to their lactate dehydrogenase activity on admission.

For $\ 245 \mathrm{U} / \mathrm{L}$ group, $3.1 \%$ of the patients were severe cases, and $1.6 \%$ of the patients died. For $245-480$ $\mathrm{U} / \mathrm{L}$ group, $40.4 \%$ of the patients were severe cases, and $1.8 \%$ of the patients died. For $480-720 \mathrm{U} / \mathrm{L}$ group, $63.6 \%$ of the patients were severe cases, and $18.2 \%$ of the patients died. For $\nabla 720 \mathrm{U} / \mathrm{L}$ group, all of the patients were severe cases, and all of the patients died. (P1凶0.001, P2ख0.001)

Higher lactate dehydrogenase activity was related to severe COVID-19 and an outcome of death.

\subsubsection{Creatine kinase activity}

\subsubsection{Highest creatine kinase activity during hospitalization}

As shown by Table 3, we grouped patients into three groups according to their highest creatine kinase activity during hospitalization. 
For $\ 200 \mathrm{U} / \mathrm{L}$ group, $19.8 \%$ of the patients were severe cases, and $2.0 \%$ of the patients died. For 200 $400 \mathrm{U} / \mathrm{L}$ group, $38.5 \%$ of the patients were severe cases, and $7.7 \%$ of the patients died. For $\$ 400 \mathrm{U} / \mathrm{L}$ group, $45.0 \%$ of the patients were severe cases, and $15.0 \%$ of the patients died. $(P 1=0.032, P 2=0.031)$

Higher creatine kinase activity was related to severe COVID-19 and an outcome of death.

\subsubsection{Creatine kinase activity on admission}

As shown by Table 4, we grouped patients into three groups according to their creatine kinase activity on admission.

For\200 U/L group, $20.4 \%$ of the patients were severe cases, and $1.9 \%$ of the patients died. For 200 $400 \mathrm{U} / \mathrm{L}$ group, $37.5 \%$ of the patients were severe cases, and $12.5 \%$ of the patients died. For $\otimes 400 \mathrm{U} / \mathrm{L}$ group, $50.0 \%$ of the patients were severe cases, and $16.7 \%$ of the patients died. $(P 1=0.020, P 2=0.010)$ Higher creatine kinase activity was related to severe COVID-19 and an outcome of death.

\subsection{Administration of gamma globulin}

Administration of gamma globulin was not used as conventional therapy method. Whether gamma globulin was used depended on the will of patients and their relatives.

As shown by Table 5, 34 severe cases were divided into two groups according to wether gamma globulin was used.

Table 5. Therapy of 34 patients with severe COVID-19

\begin{tabular}{|c|c|c|c|c|}
\hline Groups-No., \% & $\begin{array}{l}\text { All of the severe } \\
\text { cases } \\
(n=34)\end{array}$ & $\begin{array}{l}\text { Survival } \\
(n=28)\end{array}$ & $\begin{array}{r}\text { Outcomes } \\
\text { Death } \\
(\mathrm{n}=6)\end{array}$ & $\mathbf{P}$ \\
\hline \multirow[t]{2}{*}{ Severe cases treated with gamma globulin $(n=16)$} & 16/34 (47.1) & $\begin{array}{l}15 / 28 \\
(53.6)\end{array}$ & $1 / 6(16.7)$ & 0.180 \\
\hline & & $\begin{array}{l}15 / 16 \\
(93.8)\end{array}$ & $1 / 16(6.2)$ & \\
\hline \multirow[t]{2}{*}{$\begin{array}{l}\text { Severe cases treated without gamma globulin } \\
\qquad(\mathrm{n}=18)\end{array}$} & $18 / 34(52.9)$ & $\begin{array}{l}13 / 28 \\
(46.4)\end{array}$ & $5 / 6(83.3)$ & \\
\hline & & $\begin{array}{l}13 / 18 \\
(72.2)\end{array}$ & $\begin{array}{l}5 / 18 \\
(27.8)\end{array}$ & \\
\hline
\end{tabular}

For severe cases treated with gamma globulin group, $93.8 \%$ of the patients survived while $6.2 \%$ of the patients died. For severe cases treated without gamma globulin group, $72.2 \%$ of the patients survived while $27.8 \%$ of the patients died.

It seemed that administration of gamma globulin was helpful for reducing the mortality of severe cases. However the $P$ value was greater than $0.05(P=0.180)$, which mean under the same condition, studies of larger samples are needed in the future.

\section{Discussion}




\section{Underlying diseases and co-infection.}

$33.9 \%$ of all the 186 patients had one or more severe undelying diseases (i.e., chronic lung disease, chronic heart disease, chronic liver disease, chronic kidney disease) or co-infected with COVID-19 and other respiratory pathogens (i.e., Bacteria, Chlamydia pneumoniae, Mycoplasma pneumoniae, adenovirus, and respiratory syncytial virus) associated with community-acquired pneumonia, as shown by Table 1 .

Compared with cases without undelying disease or co-infection, cases with severe undelying diseases or co-infection developed to be severe cases more easily and had much higher mortality rates, as shown by Table 1.

Next, to fully assess the role of SARS-CoV-2 in COVID-19 without too much interference, we excluded 52 cases with severe underlying diseases or co-infected with COVID-19 and other respiratory pathogens associated with community-acquired pneumonia from our study, and finally 134 cases with only COVID19 were included, as shown by Figure 1 .

\section{Clinical characteristics of 134 cases of COVID-19.}

As shown by Table 2, fever, higher temperature, cough, chest tightness, headaches, fatigue were related to severe COVID-19. And age above 60 yeas old, male, higher temperature, chest tightness, headaches were related to an outcome of death.

We could see that the COVID-19 involed in multisystem of the human body, including respiratory system, nervous system, muscular system, digestive system and so on. In fact, the COVID-19 could cause damage to more than 8 systems of the human body, as reported [4]. The SARS-CoV-2 could infect a wide range of cell types by binding to ACE2 (angiotensin-converting enzyme 2), which was widely distributed in multisystem of the human body [4].

Male and the the elderly had higher mortality rates compared with female and young people. Sex differences in the response to inflammation have been documented and can be attributed, at least in part, to sex steroid hormones [5]. Moreover, age-associated decreases in sex steroid hormones, namely, estrogen and testosterone, may mediate proinflammatory increases in older adults that could increase their risk of COVID-19 adverse outcomes [5].

\section{Laboratory findings of 134 cases of COVID-19.}

When assessing the relationship between potential risk factors and the severity of COVID-19, some studies used the evaluating indicator that the highest or lowest level of candidates during hospitalization while other studies mainly used the evaluating indicator that the fixed value of candidates on admission $[1,2,3]$. What are the sphere of application and clinical significance of those two evaluating indicators? And what is the relationship between those two evaluating indicators? To answer these questions, we used both the fixed value of candidates on admission and the highest or lowest level of candidates 
during hospitalization to assess the relationship between potential risk factors and the severity of COVID19 in our study, as shown by Table 3 and Table 4.

According to Table 3 and Table 4, higher blood leukocyte count, neutrophil count, C-reactive protein level, D-dimer level, alanine aminotransferase activity, aspartate aminotransferase activity, a-hydroxybutyrate dehydrogenase activity, lactate dehydrogenase activity and creatine kinase activity were related to svere COVID-19 and an outcome of death, and so was lower lymphocyte count. We could see that similar but not the same conclusions were reached when the evaluating indicator that the fixed value of candidates on admission or the evaluating indicator that the highest or lowest level of candidates during hospitalization were used. In our opinion, to find the risk factors related to severe COVID-19 and an outcome of death, the evaluating indicator that the highest or lowest level of candidates during hospitalization might be more appropriate compared with the evaluating indicator that the fixed value of candidates on admission. That makes sense because the laboratory findings of patients on admission could be unrepresentative as the laboratory findings may vary depending on patient's health condition, and many cases that developed to be severe cases during hospitalization could be non-severe cases on admission. But why similar conclusions were also reached when the evaluating indicator that the fixed value of candidates on admission was used ? It's easy to understand because on admission some cases were already severe cases, and the blood test results of non-severe cases on admission that developed to be severe cases during hospitalization would keep increasing (i.e., blood leukocyte count, neutrophil count, C-reactive protein level, D-dimer level, alanine aminotransferase activity, aspartate aminotransferase activity, a-hydroxybutyrate dehydrogenase activity, lactate dehydrogenase activity and creatine kinase activity) or decreasing (i.e., lymphocyte count) before they reach the peak or the valley. This caused difference between non-severe group and severe group, and it made it possible for us to pick out the risk factors using statistical methods. That also mean the utility of the evaluating indicator that the fixed value of candidates on admission, was only a part of that of the evaluating indicator that the highest or lowest level of candidates during hospitalization, and under the same conditions the risk factors of Table $\mathbf{3}$ could account for more severe cases than the risk factors of Table $\mathbf{4}$, that is because under the circumstances, the difference between non-severe group and severe group of was bigger in Table 3. This view was proved by our study, for example, in Table $3>10^{\star} 10^{\wedge} 9 / \mathrm{L}$ group accounted for $73.5 \%$ of all the 34 severe cases, however, in Table $4>10^{*} 10^{\wedge} 9 / \mathrm{L}$ group only accounted for $14.7 \%$ of all the 34 severe cases. So in theory, the conclusions would be more reliable when the evaluating indicator that the highest or lowest level of candidates during hospitalization was used, compared with the evaluating indicator that the fixed value of candidates on admission. Furtherly, based on the above point of view, it is easy to understand that more attention should be paid to the patients whose blood test results keep increasing (i.e., blood leukocyte count, neutrophil count, C-reactive protein level, D-dimer level, alanine aminotransferase activity, aspartate aminotransferase activity, a-hydroxybutyrate dehydrogenase activity, lactate dehydrogenase activity and creatine kinase activity) or decreasing (i.e., lymphocyte count) during hospitalization.

Next, let us talk about the clinical significance of these risk factors. 
Leukocyte such as neutrophil, lymphocyte and monocyte are part of immune system. When human body is infected with viruses, lymphocyte count usually keeps normal or increases while neutrophil count decreases. However, in our study lymphopenia and neutrocytosis were common in patients with severe COVID-19. This abnormal phenomenon reflected the dysregulation of the immune response.

Neutrocytosis was related to Neutrophil extracellular traps (NETs), which originated from decondensed chromatin released to immobilize pathogens and could trigger immunothrombosis [6]. In addition, neutrophilic infiltration was found in a study that examined post-mor-tem biopsies from four COVID-19 patients [7]. As suggested by a previous study, the neutrocytosis might be partly caused by a dysregulated myeloid cell compartment. Severe COVID-19 was marked by occurrence of neutrophil precursors, as evidence of emergency myelopoiesis, dysfunctional mature neutrophils [8].

Lymphopenia, a marker of impaired cellular immunity, is a cardinal laboratory finding reported in $67-90 \%$ of patients with COVID-19, with prognostic association in the vast majority of studies published so far [1, 2 , 3]. Several mechanisms likely contribute to the reduced number of T cells in the blood, including effects from the inflammatory cytokine milieu and T cell recruit-ment to sites of infection [9].

C-reactive protein, a-hydroxybutyrate dehydrogenase activity and Lactate dehydrogenase belong to serum inflammatory markers. Elevation of serum inflammatory markers reflected excessive inflammation and is pre-dictive of subsequent critical illness and mortality in patients with COVID-19 $[2,3,10]$.

D-dimer reflects coagulation function. The increased D-dimer level reflected a hypercoagulable state, which might promote thrombus formation. Thrombotic complications were first reported from intensive care units in China and the Netherlands in up to $30 \%$ of patients $[11,12]$. There is also emerging evidence of thrombosis in intra-venous catheters and extracorporeal circuits, and arterial vascular occlusive events, including acute myocardial infarction, acute limb ischemia, and stroke, in severely affected people in studies from the USA (United States of America), Italy and France [4].

Alanine aminotransferase activity and aspartate aminotransferase activity were used to evaluate liver function. In critically ill patients with COVID-19, a hepatocellular injury pattern is seen in $14-53 \%$ of hospitalized patients [4]. Aminotransferases are typically elevated but remain less than five times the upper limit of nor-mal. Rarely, severe acute hepatitis has been reported [4]. In our study, we didn't see an obvious difference between $40-80 \mathrm{U} / \mathrm{L}$ group and $\$ 80 \mathrm{U} / \mathrm{L}$ group, and most of the liver fucntion were temporary and reversible. That means the liver function injury might be caused by multiple factors: immunity, inflammation and drugs.

Creatinine level was used to evaluate renal function. Acute kidney injury (AKI) is a frequent complication of COVID-19 and is associated with mortality. In China, the reported incidence of AKI in hospitalized patients with COVID-19 ranged from $0.5 \%$ to $29 \%$ and occurred within a median of 7-14 days after admission [4]. Studies from the USA have reported much higher rates of AKI. In a study of nearly 5,500 patients admitted with COVID-19 in a New Y ork City hospital system, AKI occurred in 37\%, with $14 \%$ of 
the patients requiring dialysis [4]. However the SARS-CoV-2 was not commonly found in patients' urine, that mean in most cases kidney injury was probably not directly caused by SARS-CoV-2 [13, 14].

Creatine kinase activity was used to cardiac function. SARS-CoV-2 could cause both direct cardiovascular sequelae and indirect cardiovascular sequelae, including myocardial injury, acute coronary syndromes, cardiomyopathy, acute cor pulmonale, arrhythmias, and cardiogenic shock, as well as the aforementioned thrombotic com-plications $[15,16]$.

\section{Administration of gamma globulin}

Administration of gamma globulin was not used as conventional therapy method. Whether gamma globulin was used depended on the will of patients and their relatives.

As shown by Table 5, 34 severe cases were divided into two groups according to wether gamma globulin was used. It seemed that administration of gamma globulin was helpful for reducing the mortality of severe cases. However the $P$ value was greater than $0.05(P=0.180)$, which mean under the same condition, studies of larger samples are needed in the future. In fact, gamma globulin was probably useful as suggested by several studies $[17,18]$.

\section{Conclusion}

Compared with cases with only COVID-19, cases with undelying diseases or co-infected with COVID-19 and other respiratory pathogens associated with community-acquired pneumonia developed to be severe or died more easily.

The conclusions would be more reliable when the evaluating indicator that the highest or lowest level of candidates during hospitalization was used, compared with the evaluating indicator that the fixed value of candidates on admission. It is easy to understand that more attention should be paid to the patients whose blood test results keep increasing (i.e., blood leukocyte count, neutrophil count, C-reactive protein level, D-dimer level, alanine aminotransferase activity, aspartate aminotransferase activity, ahydroxybutyrate dehydrogenase activity, lactate dehydrogenase activity and creatine kinase activity) or decreasing (i.e., lymphocyte count) during hospitalization.

Multiple factors were related to severe COVID-19 and an outcome of death. Administration of gamma globulin seemed helpful for reducing the mortality of severe cases. More related studies are needed in the future.

\section{List Of Abbreviations}

COVID-19 coronavirus disease 2019

SARS-CoV-2 severe acute respiratory syn-drome coronavirus 2 
SPSS Statistical Product and Service Solutions

ACE2 angiotensin-converting enzyme 2

USA United States of America

AKI Acute kidney injury

\section{Declarations}

\section{Statement of Ethics}

Ethics Committee of Xinzhou District People's Hospital approved this study.

\section{Consent for publication}

Not applicable

\section{Availability of data and materials}

All data generated or analysed during this study are included in this published article [and its supplementary information files].

\section{Competing interests}

The authors declare that they have no competing interests

\section{Funding}

This study was not funded by anyone.

\section{Author Contributions}

$\mathrm{JC}$ and $\mathrm{JZ}$ designed the study. RZ and JZ participated in data collection and analysis. All authors have contributed to the last version of the manuscript.

\section{Acknowledgement}

Not applicable

\section{References}

1.Guan WJ, Ni ZY, Hu Y, Liang WH, Ou CQ, He JX, Liu L, Shan H, Lei CL, Hui D et al: Clinical Characteristics of Coronavirus Disease 2019 in China. N Engl J Med 2020, 382(18):1708-1720. 
2. Zhou F, Yu T, Du R, Fan G, Liu Y, Liu Z, Xiang J, Wang Y, Song B, Gu X et al: Clinical course and risk factors for mortality of adult inpatients with COVID-19 in Wuhan, China: a retrospective cohort study. LANCET 2020, 395(10229):1054-1062.

3. Zhang G, Zhang J, Wang B, Zhu X, Wang Q, Qiu S: Analysis of clinical characteristics and laboratory findings of 95 cases of 2019 novel coronavirus pneumonia in Wuhan, China: a retrospective analysis. Respir Res 2020, 21(1):74.

4. Gupta A, Madhavan MV, Sehgal K, Nair N, Mahajan S, Sehrawat TS, Bikdeli B, Ahluwalia N, Ausiello JC, Wan EY et al: Extrapulmonary manifestations of COVID-19. NAT MED 2020, 26(7):1017-1032.

5. Al-Lami RA, Urban RJ, Volpi E, Algburi A, Baillargeon J: Sex Hormones and Novel Corona Virus Infectious Disease (COVID-19). MAYO CLIN PROC 2020, 95(8):1710-1714.

6. Middleton EA, He XY, Denorme F, Campbell RA, Ng D, Salvatore SP, Mostyka M, Baxter-Stoltzfus A, Borczuk AC, Loda M et al: Neutrophil extracellular traps contribute to immunothrombosis in COVID-19 acute respiratory distress syndrome. BLOOD 2020, 136(10):1169-1179.

7. Tian S, Xiong Y, Liu H, Niu L, Guo J, Liao M, Xiao S: Pathological study of the 2019 novel coronavirus disease (COVID-19) through postmortem core biopsies. MODERN PATHOL 2020, 33(6):1007-1014.

8. Schulte-Schrepping J, Reusch N, Paclik D, Bassler K, Schlickeiser S, Zhang B, Kramer B, Krammer T, Brumhard S, Bonaguro L et al: Severe COVID-19 Is Marked by a Dysregulated Myeloid Cell Compartment. CELL

9. Vabret N, Britton GJ, Gruber C, Hegde S, Kim J, Kuksin M, Levantovsky R, Malle L, Moreira A, Park MD et al: Immunology of COVID-19: Current State of the Science. IMMUNITY 2020, 52(6):910-941.

10. Ruan Q, Yang K, Wang W, Jiang L, Song J: Correction to: Clinical predictors of mortality due to COVID19 based on an analysis of data of 150 patients from Wuhan, China. Intensive Care Med 2020, 46(6):1294-1297.

11. Cui S, Chen S, Li X, Liu S, Wang F: Prevalence of venous thromboembolism in patients with severe novel coronavirus pneumonia. J THROMB HAEMOST 2020, 18(6):1421-1424.

12. Klok FA, Kruip M, van der Meer N, Arbous MS, Gommers D, Kant KM, Kaptein F, van Paassen J, Stals M, Huisman MV et al: Incidence of thrombotic complications in critically ill ICU patients with COVID-19. THROMB RES 2020, 191:145-147.

13. Puelles VG, Lutgehetmann M, Lindenmeyer MT, Sperhake JP, Wong MN, Allweiss L, Chilla S, Heinemann A, Wanner N, Liu S et al: Multiorgan and Renal Tropism of SARS-CoV-2. N Engl J Med 2020, 383(6):590-592. 
14. Ling Y, Xu SB, Lin YX, Tian D, Zhu ZQ, Dai FH, Wu F, Song ZG, Huang W, Chen J et al: Persistence and clearance of viral RNA in 2019 novel coronavirus disease rehabilitation patients. Chin Med J (Engl) 2020, 133(9):1039-1043.

15. Driggin E, Madhavan MV, Bikdeli B, Chuich T, Laracy J, Biondi-Zoccai G, Brown TS, Der Nigoghossian C, Zidar DA, Haythe J et al: Cardiovascular Considerations for Patients, Health Care Workers, and Health Systems During the COVID-19 Pandemic. J AM COLL CARDIOL 2020, 75(18):2352-2371.

16. Clerkin KJ, Fried JA, Raikhelkar J, Sayer G, Griffın JM, Masoumi A, Jain SS, Burkhoff D, Kumaraiah D, Rabbani L et al: COVID-19 and Cardiovascular Disease. CIRCULATION2020, 141(20):1648-1655.

17. Basic-Jukic N: Can hyperimmune anti-CMV globulin substitute for convalescent plasma for treatment of COVID-19? MED HYPOTHESES 2020, 144:109903.

18. Sun L, Shen L, Fan J, Gu F, Hu M, An Y, Zhou Q, Fan H, Bi J: Clinical features of patients with coronavirus disease 2019 from a designated hospital in Beijing, China. J MED VIROL

\section{Figures}

186 confirmed cases with COVID-19

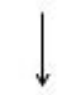

14 cases with severe underlying diseases were excluded

22 cases with common bacteria or viruses associated with community-acquired pneumonia were excluded

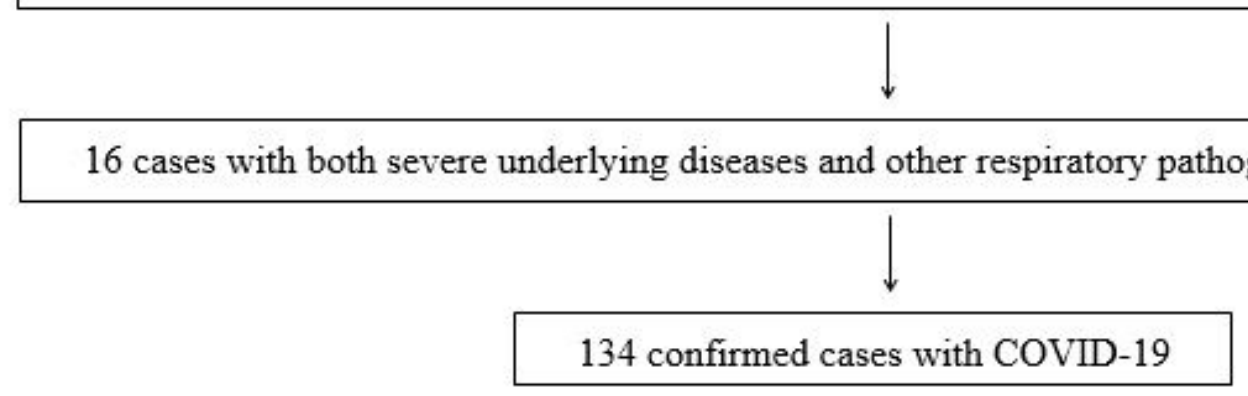

Figure 1

A flow chart, from the total number of patients up to the 134 patients of the study. 14 cases with severe underlying diseases (i.e., chronic lung disease, chronic heart disease, chronic liver disease, chronic kidney disease) were excluded. 22 cases co-infected with 2019 novel coronavirus and other respiratory pathogens (i.e., Bacteria, Chlamydia pneumoniae, Mycoplasma pneumoniae, adenovirus, and respiratory syncytial virus) associated with community-acquired pneumonia were excluded. 16 cases with both 
severe underlying diseases and other respiratory pathogens infection were excluded. Finally 134 confirmed cases with COVID-19 were included into our study. 